\title{
CONTRIBUTIONS FROM THE COOPERATIVE STUDY OF SECONDARY-SCHOOL STANDARDS
}

\author{
Edgar G. Johnston \\ University of Michigan; Field Representative, Coöperative Study
}

I believe it is the considered conviction of those who have worked intimately with secondary schools—or for that matter with any other human institution-that improvement comes, not from imposition or regimentation from without, but rather from increased vision and insight on the part of those responsible for the program. The contribution of the Coöperative Study of Secondary-School Standards is to be judged largely from the extent to which it has furnished stimulus to self-study and enrichment of pupil experience for those schools which have made use of its materials and its technique. Briefly, the procedure of the Study may be characterized as an intensive self-survey by a school, supplemented by an impartial review by an objective but sympathetic visiting committee.

I can best illustrate its procedure by showing you with the aid of slides some of the materials with which the Study works and the nature of the information and the coopperating school is enabled to secure about itself. I am taking it for granted that through the published information about the Study and Dr. Eells' presentation to this group last year you are familiar in a general way with the history and development of the Study up to the current year.

You will remember that the General Committee of the Coöperative Study set itself the task of securing answers to four fundamental questions:

1. What are the characteristics of a good secondary school?

2. What practicable means and methods may be employed to evaluate the effectiveness of a school in terms of its objectives?

3. By what means and processes does a good school develop into a better one?

4. How can regional associations stimulate secondary schools to continuous growth?

The chief instrument for enabling a school to study its own procedures is the set of Evaluative Criteria, which, in its 1938 edition, includes eleven sections and comprises a total of 152 pages of analytic data.

\section{EVALUATIVE CRITERIA}

Outline of Contents

Basic Information

B. Philosophy and Objectives

C. Pupil Population and School Community 


\author{
Educational Program \\ D. Curriculum and Courses of Study \\ E. Pupil Activity Program \\ F. Library Service \\ G. Guidance Service \\ H. Instruction \\ I. Outcomes \\ Staff, Plant, Administration \\ J. School Staff \\ K. School Plant \\ L. School Administration
}

It will be noted that the first two sections, referred to as Basic Information, involve the philosophy of the school-what it as a school conceives to be its function-and the characteristics of the pupils who constitute its student body and of the community it serves. These two sections serve as a sort of "frame of reference" against which the school's performance in the other areas is to be judged. It is obvious that the problems of a small rural high school differ markedly from those of a secondary school in a metropolitan community or of a private school with the shadow of College Boards hanging over its head. It is the conviction of those in charge of the Coöperative Study that an instrument designed to assist in solution of those problems should be sufficiently flexible to be adapted to various conditions and to take into account varying philosophies and community situations.

The other sections provide for a detailed review of the various factors which go into the making of a good school. It will be noted that major emphasis is placed on the different phases of the educational programs. Too frequently school excellence has been determined in terms of material equipment and administrative efficiency.

The technique of the Study can best be shown by consideration of a sample portion of one of the component sections.

\title{
THE SCHOOL ASSEMBLY
}

CHECKLIS!

$(+)$ 1. School assembly programs are in large part given by pupils and by pupil organizations with pupils presiding.

(O) 2. Assembly programs are planned so as to secure participation and contributions of many, not simply of the few.

(-) 3. Assembly programs have definite entertainment, instructional, cultural, and inspirational values.

$(+)$ 4. Assembly programs are free from coarse and objectionable elements.

(+) 5. Assembly programs are characterized by a variety of presentation, such at music, speaking, dramatization, demonstration, and exhibits.

(-) 6. Assembly progranss stimulate the creative ability of pupils by encouraging them to write and produce plavs or other performances, design scenery and costumes, devise unusual exhibitions and entertainments, etc. 
(O) 7. Correct audience habits are developed-no late-comers or earlyleavers; reasonable applause, courteous attention to performers; no disturbances.

() 8 .

Number of school assemblies per year, 15.

Length of assembly period, 30 minutes.

Evalitations

(4) w. How adequate are the provisions for attaining conditions or results such as the above?

(3) $x$. How effectively are these conditions or results attained?

(2) y. How actively and axtensively do pupils participate in the presentation of programs?

(3) z. Evaluate the quality of four successive assembly programs.

comments:

Average Evaluation $=\frac{12}{4}=3.0$

Figure I.

Figure I presents a part of one page of one section-that dealing with Pupil Activities. You will observe that there are two distinct features of the survey presented here-check list items and evaluations. The items of the check list present what are generally accepted as sound principles applicable to the conduct of school assemblies. Through use of the symbols, "十," “-," and "O," the school presents its judgment as to the degree of attainment of these provisions or conditions in its own situation. It is encouraged under Comments and through presentation of supplementary materials to indicate outstanding achievements, peculiar conditions, modifying factors, points of disagreement with the principles stated-anything which may contribute to a more adequate picture of the school's performance in this field.

The school then presents under Evaluations its estimate of the success of its performance in the light of this review. The symbols used here range from " 5 ," representing outstanding achievement, to " 1, " which indicates little or no success in the phase under consideration.

Obviously, the intensive self-analysis provided by the study of its assembly procedures enables the school both to appraise more effectively its achievements in this field, and to plan intelligently for improvement. Similar analyses are made for the other sections of the Evaluative Criteria which I described to you earlier. The school is urged to involve all members of its staff in some phase of the evaluation, and the experience of those of us who have been working with the Study this year has been that one result of participation by a school has been an increased interest of teachers in the entire school program.

If the school does no more than to apply these criteria to its own program as conscientiously and objectively as it can, the results should be extremely valuable. The technique of the Coöperative Study, however, provides two further steps which increase the validity of the analysis. The first is the review by a visiting committee. This reviewing board, appointed 
ordinarily by the state committee of the regional accrediting association, includes in its membership active administrators of other secondary schools as well as representatives of state departments of education and of higher institutions in the area. It spends sufficient time in the school-ordinarily from two days to a week, depending on the size of the school-to enable it to become thoroughly familiar with the procedures and instruction of the school. I shall not go into detail in description of the procedures of such a committee. You will find them fully discussed in Chapter VII of the monograph, How to Evaluate a Secondary School.* It may be observed that this review gives the school the benefit of the judgment of "outsiders" and serves the purpose of correcting errors of judgment due to complacency or an inadequate standard of comparison.

A further advantage comes to the school in the comparison of its effectiveness in the various areas included in the Evaluative Criteria with typical practice, through computation of scores and their representation on Educational Thermometers. I shall not go into the procedures used in developing these thermometers, since that has been exhaustively described in articles in various publications and in the monograph to which I referred earlier.** I do wish to illustrate briefly the type of report which comes back to the school and the use which may be made of it for improvement of the program.

A sample thermometer is shown in Figure II (see p. 42, Bulletin 73 of the Department of Secondary-School Principals), in this case representing the number of books in the library. You will observe that it is a percentile scale, the graduations on the left side of the scale showing the level reached by the designated proportion of the schools included, while on the right are shown the numbers of volumes corresponding to these levels. You will also note that norms are indicated, showing the average score for schools grouped according to regions and other bases of classification. In all, one hundred such thermometers are given, enabling a school to compare itself with typical procedure in many details for each section of the Evaluative Criteria.

The significance of these thermometers to a school may best be shown by presenting sample pages of the reports sent back to an actual school, in this case the median school-that one whose performance was excelled by as many schools as were inferior to it.

The important thing in Figure III is the profile-the designation of strong and weak points. It should be a matter of concern to this school that in curriculum it reached only the 11 th percentile, that guidance was at the 34 th, instruction at the 30 th, and outcomes at the 37 th. The fact that it has an average plant and distinctly superior staff and library sug-

*Cooperative Study of Secondary School St:undards, How to Evaluate a Secondary School. Washington, D. C., 1938. Pp. 55-62.

Ibid., Chapters V. IX, X, XI. 
gest that it is certainly not getting adequate returns from its "capital." A study of the check list items which were scored as unsatisfactory in the evaluation of the school should enable it to direct its energies toward the improvement of those areas which rank low.

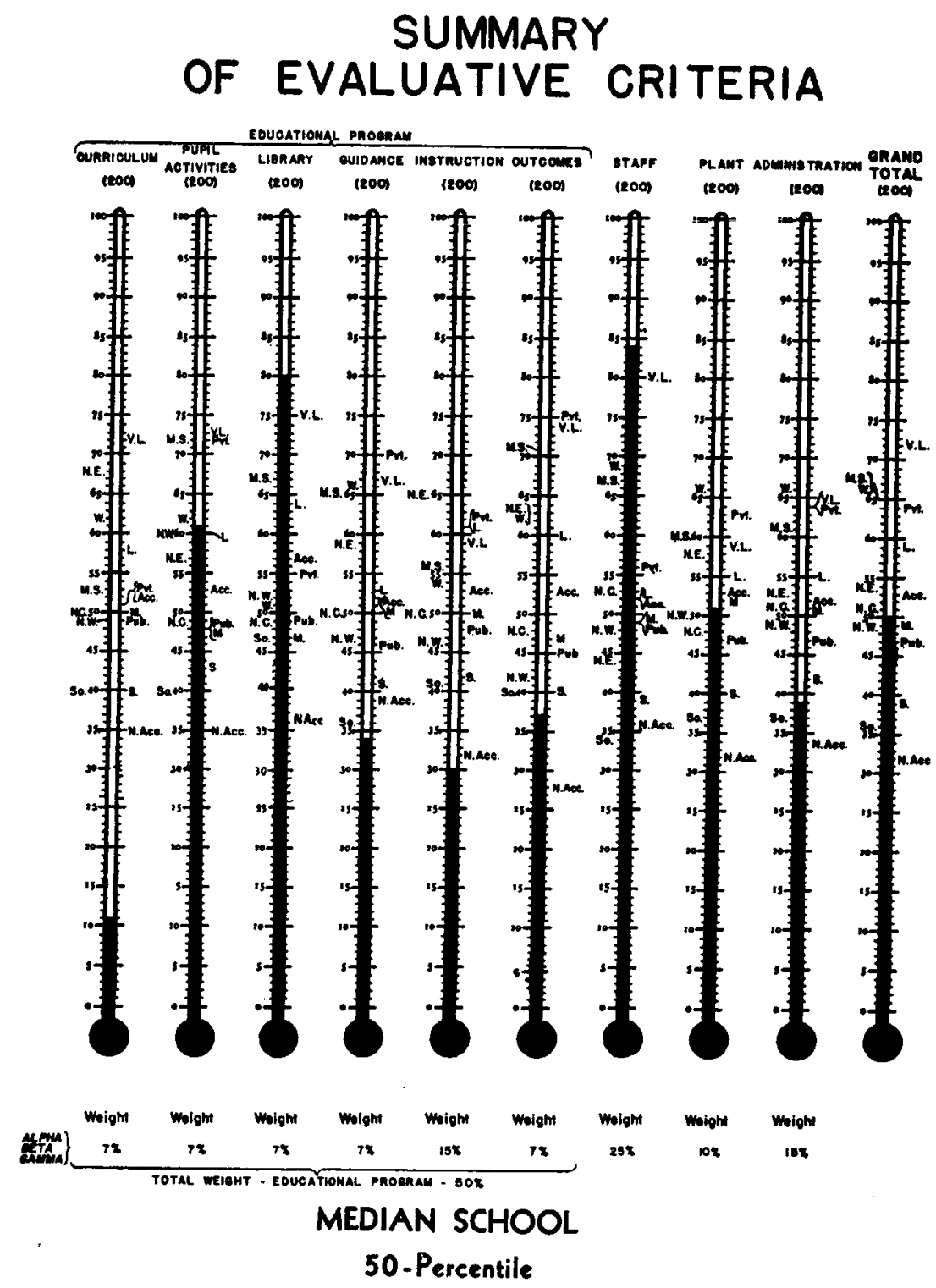

Figure III. 
The significance of this "profile" is shown more clearly as we consider the showing in detail in one of the areas, here pupil activities.

It will be noted from Figure IV that while the showing on the area as a whole is above average, certain parts of the program-home roons, assemblies, and administration of finances--are distinctly inferior. The

\section{PUPIL ACTIVITY PROGRAM}

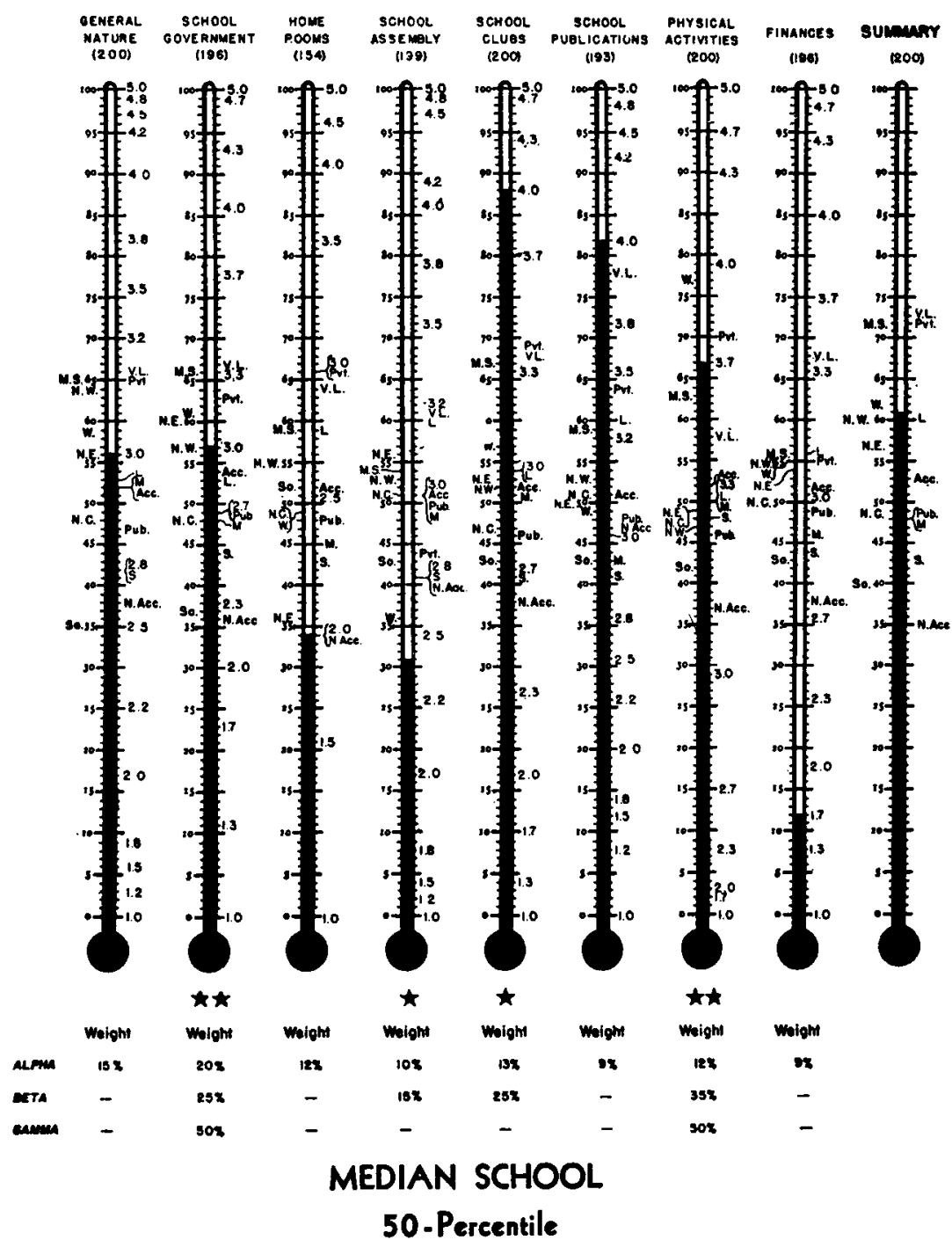

Figure IV. 
staff should give serious attention to the improvement of these phases of its program, while maintaining its clubs and publications at the high level indicated. Time precludes going into further detail in regard to the use of these "Educational Temperatures." It should be evident that they serve to provide the school with a series of yardsticks by which its performance may be judged.

The title assigned to me for this afternoon's session was "Significant Contributions to Secondary-School Improvement from the Coopperative Study of Secondary School Standards." I trust that the illustrations drawn from the materials provided by the Study have served in some measure to show what those contributions are. If I may be permitted to summarize them briefly, I should say that there seem to me to be three chief contributions from the Coöperative Study materials and technique:

In the first place it stimulates the school to an intensive study of its own program and problems. I can think of no other approach from which any intelligent efforts at improvement can take their beginning.

The second contribution of the Coöperative Study is a new relationship in supervision. Under this plan, the supervising agency-state department, higher institution, or accrediting association-enters the picture not as an ex officio judge with authority to hand down an opinion as to what is wrong with the school, but as a friendly helper prepared to assist the school to a more accurate evaluation of itself. It is significant that while the Study was initiated in an effort to provide a more valid basis of accreditation, the emphasis on the part of those who have made most effective use of its methods has shifted from accreditation to stimulation and assistance.

Finally, and a point of no small significance, it places the responsibility for improvement of secondary education where, in my judgment, it belongs, on the shoulders of the responsible leaders of our secondary schools. The school which has made a careful evaluation of its own program and is planning improvements in the light of that study will exert an influence for more functional education in its area. The majority of the members of reviewing committees are drawn from active administrators of other schools in the locality. The day of college domination of the high school has passed. Increasingly its course of development will be determined by teachers and principals of American high schools aware of the problems facing the school and grappling at first hand with their solution. "Standards for secondary schools" are in the hands of this group. It is in this field that the National Department of Secondary-School Principals appropriately aspires to leadership. It cannot afford to overlook the assistance to that effort which may be found in intelligent use of the materials and methods provided by the Coöperative Study of Secondary School Standards.

Discussion followed. 


\section{JUNIOR COLLEGE DIVISION}

The Junior-College Division was held in the Ball Room Annex of the Public Auditorium with the theme of The Junior College Serving Its Sectional Needs.

Mr. M. G. Jones, Principal of Union High School, Huntington Beach, California, and Member of the Executive Committee of the Department of Secondary-School Principals, introduced the program by presenting Mr. J. L. McCaskill, Principal of Senior High School and Junior College of Meridian, Mississippi, who read his paper, Problems in Evolving a JuniorCollege Curriculum to Meet Community Needs.

\section{JUNIOR COLLEGE DIVISION \\ PROBLEMS IN EVOLVING A JUNIOR COLLEGE CURRICULUM TO MEET COMMUNITY NEEDS \\ J. L. McCaskill}

Principal of Senior High School and Junior College, Meridian, Mississippi

The change from the six-three-three to the six-four-four plan of school organization in Meridian, Mississippi, is so recent that no measurable results that are defensible can be reported. The reasons for the decision to change to the six-four-four plan, the procedure that was used in an attempt to determine the educational needs of the community, and the first steps that were taken in instituting the change may be of value especially to those of you who may contemplate a similar change in organization.

The Meridian school system serves a district that is seventy-two square miles in area and has a population of approximately fifty thousand people. About sixty-five per cent of the population is American-born white, thirtyfive per cent negro, and less than one per cent foreign born. The system has separate schools for whites and colored, and my discussion will deal entirely with the white schools. The community is primarily an industrial one. The enrollment in the Senior High School division at the beginning of the reorganization was approximately eight hundred.

The decision to change the plan of organization of the school system from the six-three-three to the six-four-four was made by the community after the presentation of the following facts:

1. That the geographical location of Meridian with reference to higher educational institutions was such that opportunity for education beyond high school was naturally limited. The nearest four-year college was a hundred miles away.

2. That changing economic conditions were making employment for high-school graduates extremely difficult. 